\title{
ERBB2 NP_004439.2:p.A775_G776insYVMA
}

National Cancer Institute

\section{Source}

National Cancer Institute. ERBB2 NP 004439.2:p.A775 G776insYVMA. NCI Thesaurus. Code $C 98359$.

An insertion of the amino acid sequence tyrosine-valine-methionine-alanine between the alanine at position 775 and the glycine at position 776 of the receptor tyrosine-protein kinase erbB-2 protein. 